\title{
A Study on Growth Performance of Weaned Kids of Sirohi Goat Fed with Different Levels of Concentrates
}

\author{
Hanuman Lal Nehra ${ }^{1 *}$, Athar Uddin ${ }^{1}$ and Vinod Bhateshwar ${ }^{2}$ \\ ${ }^{1}$ Department of Livestock Production Management, Sri Karan Narendra Agriculture University, Jobner (Raj.) INDIA \\ ${ }^{2}$ Department of Animal Husbandry and Dairying, Banaras Hindu University, Varanasi (U.P.) INDIA
}

"Corresponding author: H L Nehra; E-mail: nehrahl70@gmail.com

Received: 16 Feb., 2020

Revised: 14 March, 2020

Accepted: 22 March, 2020

\begin{abstract}
The present investigation was conducted a study on growth performance of weaned kids of Sirohi goat fed with different levels of concentrates for the effect of concentrate feeding on body weight gain. Twenty four kids of Sirohi breed between 3-4 months age were randomly selected on the basis of uniform body weight, age and divided into 3 groups of 8 kids each at the goat farm of S.K.N. College of Agriculture, Jobner. Group $\mathrm{T}_{1}$ served as control supplemented with $50 \mathrm{~g}$ concentrate per kid per day for 3 months. Group $\mathrm{T}_{2}$ (treatment) supplemented with 50,100 and $150 \mathrm{~g}$ concentrate and $\mathrm{T}_{3}$ (treatment) with 100, $150 \mathrm{gnd} 200 \mathrm{~g}$ concentrate per head per day for $1^{\text {st }}, 2^{\text {nd }}$ and $3^{\text {rd }}$ month, respectively. Other management practices were similar for each group. Fodder of khejri loom was offered ad-libitum to all groups. Body weight of kids was recorded weekly. Group $\mathrm{T}_{3}$ fed with more quantity of concentrate achieved the highest $(85.77 \mathrm{~g} /$ day $)$ average weekly weight gain followed by $\mathrm{T}_{2}(69.22 \mathrm{~g} /$ day $)$ and control group $\mathrm{T}_{1}(61.33 \mathrm{~g} /$ day $)$. Maximum average total weight gain per kid was observed in group $\mathrm{T}_{3}(7.72 \mathrm{~kg})$ followed by $\mathrm{T}_{2}(6.23 \mathrm{~kg})$ and least was found in $\mathrm{T}_{1}(5.52 \mathrm{~kg})$. Thus, from above findings it can be concluded that $\mathrm{T}_{2}$ and $\mathrm{T}_{3}$ treatments showed significantly improved growth performance in Sirohi kids and higher level $\left(\mathrm{T}_{3}\right)$ was relatively the best level in terms of both biological and economical returns.
\end{abstract}

Keywords: Concentrates, Weight gain, Sirohi kids

Small ruminants are the major economically important livestock in the country. They provide meat, milk, skin, hair, fiber and manure for cash, security, gifts, medicine, etc. The role of small ruminants is more pronounced in the arid and semi-arid zone of country because of the uncertainty of crop production due to drought and many other reasons.

Goats have multifaceted utility as a livestock species and play significant role in rural economy. Rearing of goats is very useful for small and marginal farmers and landless labourers especially in the areas, where crops and dairy farming are not economical. Goat plays an important role in generating employment in rural areas. Being small in size, they do not require any large management skills and can be easily handled and managed by women and children. Goats can survive in areas with low quality vegetation. In
India, goats are mainly fed on crop residues, green fodder, top feeds and non-conventional feed resources.

Goat meat has no religious taboo and the market for it is well established. They are traditionally raised by poverty stricken village people in a secondary system of grazing on harvested fellow land, along the road and canal sides, community pasture land without any supplementation. For the poor farmers who are unable to maintain large ruminants, goat justifies its designation as "the poor man's cow". Under the changing agro-geo-climatic conditions and depleting resources for livelihood, the goat has tremendous potential to be projected as the 'Future Animal' for rural prosperity.

How to cite this article: Nehra, H.L., Uddin, A. and Bhateshwar, V (2020). A study on growth performance of weaned kids of Sirohi goat fed with different levels of concentrates. J. Anim. Res., 10(2): 247-251. 
Supplementation of concentrates is important for growth and productivity of goats. By feeding good quality concentrate we can satisfy requirement of both protein and energy. Increasing concentrate levels in kid diet results in increased live weight, as well as carcass weight (Ryan et al., 2007). However, reports on the nutrient requirements are scanty and very little information is available particularly on the contribution of dietary protein and energy to the performance of growing kids under farm conditions and the cost benefit of feeding additional concentrates has not been fully explored in goat-production systems and needs to be evaluated. The quality and quantity of concentrate fed to growing kids has got very much importance for their maintenance and weight gain. Many farmers in India rear goats for the purpose of meat production and for them the growth is most valuable.

Improved livestock production could be achieved through cultivation of high quality forage adapted to local conditions as well as feeding concentrate. Concentrate feed promote rapid growth of goat, reduced ruminal methane production and increase ruminal propionate production, thereby lowering energy losses and contributing to higher overall efficiency of utilization of dietary energy for body weight gain (Mandebvu and Galbraith, 1999). Therefore, tree foliage or forage based ruminant feeding with an appropriate level of concentrate may provide optimum nutrient balance to improve animal productivity. Existing feedstuffs in tropical countries often provide inadequate energy, protein, minerals and vitamins to support optimum animal productivity (Reed et al., 1990). Growing small ruminants supplemented with concentrates in addition to grazing in semi-arid regions of India is the prevailing kid production system, however, their growth performance is not optimum (Karim et al., 2007). Therefore, Khejri foliage or forage based ruminant feeding with an appropriate level of concentrate may provide nutrient balance to improve animal productivity.

\section{MATERIALS AND METHODS}

The experiment was conducted at goat farm, S.K.N. college of Agriculture, S.K.N. Agriculture University Jobner, District Jaipur, (Rajasthan, India). Twenty four Sirohi goat kids of either sex having approximately uniform body weight and age group (4 months) were selected. These kids were divided into three equal groups consisting of eight kids in each group and the study was carried out for a period of thirteen weeks. The experiment was conducted using randomized block design.

Table 1: Distribution of experimental Sirohi goat kids

\begin{tabular}{lll}
\hline Treatments & No. of Animals & Average body weight (in kg) \\
\hline $\mathrm{T}_{1}$ & 08 & $11.05 \pm 0.80$ \\
$\mathrm{~T}_{2}$ & 08 & $11.08 \pm 0.71$ \\
$\mathrm{~T}_{3}$ & 08 & $11.03 \pm 0.78$ \\
\hline
\end{tabular}

Similar housing and managemental facilities were provided to all the groups. Animals were penned in wellventilated enclosures for the experiment. The concentrate mixture in pelleted form was obtained from local market Concentrate and roughages were fed separately to each kid in all treatment groups. The concentrate was fed once in a day at 10:00 am. Whereas, the roughage (khejri loom) was offered at 10:30 am and 4:00 pm to all treatment groups. Ad-libitum clean drinking water was available round the clock to all treatment groups. All the experimental kids were weighed early in the morning, before offering the feed, at weekly intervals upto 13 weeks from the commencement ( 4 months of age) of the experiment. Weighing was carried out by digital weighing balance/electronic. The experimental kids were weighed individually at the start of the experiment and at weekly intervals thereafter, up to 90 days on weighing balance.

Table 2: Feeding schedule of weaned kids of Sirohi goat

\begin{tabular}{llll}
\hline $\begin{array}{l}\text { Experimental } \\
\text { period (days) }\end{array}$ & $\mathbf{T}_{\mathbf{1}}$ & $\mathbf{T}_{\mathbf{2}}$ & $\mathbf{T}_{\mathbf{3}}$ \\
\hline \multirow{3}{*}{$0-30$} & \multicolumn{4}{c}{ Concentrate supplementation gram/head/day } \\
\cline { 2 - 3 } $31-60$ & 50 & 50 & 100 \\
$61-90$ & 50 & 100 & 150 \\
\hline
\end{tabular}

Table 3: Chemical composition (\% DM Basis) of concentrate mixture

\begin{tabular}{ll}
\hline Nutrients & Percentage \\
\hline Total digestible nutrient (TDN) & $75 \%$ \\
Crude protein (CP) & $18 \%$ \\
Crude fibre (CF) & $10 \%$ \\
Common salt (CS) & $1.0 \%$ \\
Mineral mixture (M.M.) & $2.0 \%$ \\
\hline
\end{tabular}




\section{STATISTICAL ANALYSIS}

Statistical analysis was carried out by standard statistical methods RBD and the calculation of ANOVA was done. This formula was given by Fisher and Yates (1950). Superscripts are used for significantly difference in means by DMRT method. Duncan's new multiple range test (DMRT) is a multiple comparison procedure developed by David B. Duncan in 1955.

\section{RESULTS AND DISCUSSION}

\section{Weekly body weight}

The initial body weight of kids in group $\left(\mathrm{T}_{1}\right),\left(\mathrm{T}_{2}\right)$ and $\left(\mathrm{T}_{3}\right)$ were recorded as $11.05,11.08$ and $11.03 \mathrm{~kg}$ and final body weights of kids at the end of experiment as 16.57 , 17.31 and $18.73 \mathrm{~kg}$, respectively. There was a progressive increase in the body weight in all groups, the weekly body weight of kids of different groups is presented in (Table 4).

Table 4: Average weekly body weight $(\mathrm{kg})$ of Sirohi kids from different experimental groups

\begin{tabular}{|c|c|c|c|c|c|}
\hline Weeks & $\begin{array}{c}T_{1} \text { (Mean } \\
\pm \mathrm{SE})\end{array}$ & $\begin{array}{c}T_{2}(\text { Mean } \pm \\
\text { SE) }\end{array}$ & $\begin{array}{c}\mathrm{T}_{3}(\text { Mean } \pm \\
\text { SE) }\end{array}$ & $\begin{array}{c}\text { Total Mean } \\
\pm \mathrm{SE}\end{array}$ & $\begin{array}{c}\text { P- } \\
\text { Value }\end{array}$ \\
\hline Initial & $11.05 \pm 0.80$ & $11.08 \pm 0.71$ & $11.03 \pm 0.78$ & $11.05 \pm 0.42$ & 0.09 \\
\hline 1 & $11.42 \pm 0.80$ & $11.43 \pm 0.71$ & $11.47 \pm 0.79$ & $11.44 \pm 0.42$ & 0.09 \\
\hline 2 & $11.81 \pm 0.80$ & $11.80 \pm 0.72$ & $11.95 \pm 0.79$ & $1.85 \pm 0.42$ & 0.08 \\
\hline 3 & $12.20 \pm 0.79$ & $12.18 \pm 0.72$ & $12.48 \pm 0.78$ & $12.29 \pm 0.42$ & 0.07 \\
\hline 4 & $12.65 \pm 0.80$ & $12.58 \pm 0.71$ & $13.06 \pm 0.77$ & $12.76 \pm 0.42$ & 0.06 \\
\hline 5 & $13.10 \pm 0.80$ & $13.05 \pm 0.71$ & $13.55 \pm 0.79$ & $13.23 \pm 0.43$ & 0.06 \\
\hline 6 & $13.56 \pm 0.80$ & $13.56 \pm 0.72$ & $14.33 \pm 0.79$ & $13.82 \pm 0.43$ & $0.05 *$ \\
\hline 7 & $14.02 \pm 0.80$ & $14.13 \pm 0.72$ & $15.02 \pm 0.80$ & $14.39 \pm 0.44$ & $0.04 *$ \\
\hline 8 & $14.51 \pm 0.79$ & $14.72 \pm 0.72$ & $15.73 \pm 0.79$ & $14.99 \pm 0.44$ & $0.03 *$ \\
\hline 9 & $15.01 \pm 0.79$ & $15.33 \pm 0.73$ & $16.45 \pm 0.80$ & $15.60 \pm 0.44$ & $0.02 *$ \\
\hline 10 & $15.52 \pm 0.79$ & $15.96 \pm 0.73$ & $17.18 \pm 0.80$ & $16.22 \pm 0.45$ & $0.01 *$ \\
\hline 11 & $16.03 \pm 0.80$ & $16.62 \pm 0.73$ & $17.95 \pm 0.81$ & $16.87 \pm 0.46$ & $0.01 *$ \\
\hline 12 & $16.57 \pm 0.80$ & $17.31 \pm 0.73$ & $18.73 \pm 0.82$ & $17.54 \pm 0.47$ & $0.008^{*}$ \\
\hline
\end{tabular}

* Significant at $5 \%$ level.

From the present study it is found that the overall body weight of Sirohi kids significantly $(\mathrm{P} \leq 0.05)$ increased with increase in level of concentrate supplementation. The results obtained in present trial are in agreement with Kharkar et al. (2014) who reported the body weight at 3 and 6 months of age as $10.60+0.67$ and $15.08+0.30$ respectively in Berari goats. Mandakmale et al. (2012) reported lower average body weights for Sangamneri male kids at 3 and 6 months of age $(8.98 \pm 0.08$ to 14.09 $\pm 0.21 \mathrm{~kg}$ ). Anil Kumar et al. (2009) reported that the body weight of the ewes was higher in treatment group over control, which were fed higher amount of concentrates were significantly heavier than ewes receiving lesser amounts of concentrates.

\section{Weekly gain in body weight}

The average weekly weight gain of kids in $\mathrm{T}_{1}, \mathrm{~T}_{2}$ and $\mathrm{T}_{3}$ groups increased from 0.37 to $0.54,0.35$ to 0.69 and 0.44 to $0.78 \mathrm{~kg} /$ week in first and last week of experiment, respectively. It is also observed that the overall average weekly weight gain was $0.46,0.52$ and $0.64 \mathrm{~kg} /$ week in $\mathrm{T}_{1}, \mathrm{~T}_{2}$ and $\mathrm{T}_{3}$ groups, respectively (Table 5) and the same is also graphically depicted in (Fig. 1). The overall effect of concentrate supplement on weekly weight gain was found significantly different between $\mathrm{T}_{1}$ and $\mathrm{T}_{2}$.

Table 5: Average weekly weight gain (kg/week) of Sirohi kids in different groups

\begin{tabular}{cccccc}
\hline Weeks & $\begin{array}{c}\mathbf{T}_{1} \text { (Mean } \pm \\
\text { SE) }\end{array}$ & $\begin{array}{c}\mathbf{T}_{\mathbf{2}} \text { (Mean } \\
\pm \text { SE) }\end{array}$ & $\begin{array}{c}\mathbf{T}_{\mathbf{3}}(\text { Mean } \\
\pm \text { SE) }\end{array}$ & $\begin{array}{c}\text { Total } \\
\text { Mean } \pm \\
\mathbf{S E}\end{array}$ & $\begin{array}{c}\mathbf{P} \text { - } \\
\text { value }\end{array}$ \\
\hline 1 & $0.37 \pm 0.02$ & $0.35 \pm 0.51$ & $0.44 \pm 0.06$ & $0.39 \pm 0.02$ & 0.09 \\
2 & $0.39 \pm 0.02$ & $0.37 \pm 0.03$ & $0.48 \pm 0.08$ & $0.41 \pm 0.03$ & 0.08 \\
3 & $0.39 \pm 0.02$ & $0.38 \pm 0.04$ & $0.53 \pm 0.11$ & $0.43 \pm 0.05$ & 0.08 \\
4 & $0.44 \pm 0.04$ & $0.40 \pm 0.03$ & $0.58 \pm 0.06$ & $0.47 \pm 0.07$ & 0.07 \\
5 & $0.45 \pm 0.06$ & $0.47 \pm 0.07$ & $0.61 \pm 0.08$ & $0.51 \pm 0.08$ & 0.07 \\
6 & $0.46 \pm 0.07$ & $0.51 \pm 0.08$ & $0.66 \pm 0.06$ & $0.54 \pm 0.11$ & 0.06 \\
7 & $0.46 \pm 0.06$ & $0.57 \pm 0.09$ & $0.69 \pm 0.07$ & $0.57 \pm 0.09$ & 0.05 \\
8 & $0.49 \pm 0.06$ & $0.59 \pm 0.06$ & $0.71 \pm 0.08$ & $0.60 \pm 0.08$ & 0.05 \\
9 & $0.50 \pm 0.07$ & $0.61 \pm 0.05$ & $0.72 \pm 0.13$ & $0.61 \pm 0.08$ & 0.05 \\
10 & $0.51 \pm 0.13$ & $0.63 \pm 0.08$ & $0.73 \pm 0.14$ & $0.62 \pm 0.07$ & $0.04 *$ \\
11 & $0.51 \pm 0.05$ & $0.66 \pm 0.09$ & $0.77 \pm 0.08$ & $0.65 \pm 0.09$ & $0.03^{*}$ \\
12 & $0.54^{\mathrm{a}} \pm 0.05$ & $0.69^{\mathrm{b}} \pm 0.12$ & $0.78^{\mathrm{b}} \pm 0.10$ & $0.67 \pm 0.10$ & $0.02^{*}$ \\
Average & $0.46^{\mathrm{b}} \pm 0.01$ & $0.52^{\mathrm{b}} \pm 0.03$ & $0.64^{\mathrm{c}} \pm 0.02$ & $0.54 \pm 0.02$ & $0.04^{*}$ \\
\hline
\end{tabular}

* Significant at $5 \%$ level.

Furthermore, effect of three treatments at each week was not significantly different; however, there was no significant difference in weekly increase in weight. The 
kids from group $\mathrm{T}_{3}$ fed with higher quantity of concentrate expressed significantly higher (640 g / week) weekly weight gain followed by $\mathrm{T}_{2}(520 \mathrm{~g} /$ week). The present results are similar to those reported by Ferdous et al. (2011) and Mule et al. (2014) who also reported an increased weekly weight gain in kids, respectively, with increasing level of concentrate feeding.

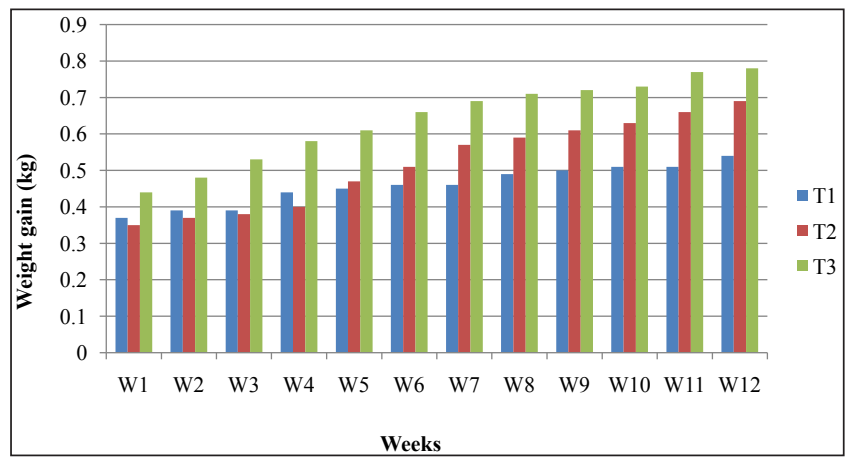

Fig. 1: Average weekly weight gain ( $\mathrm{kg} /$ week) of Sirohi kids in different groups

\section{Monthly gain in body weight}

Monthly weight gain of the Sirohi kids increased from 1.60 to $2.06 \mathrm{~kg}\left(\mathrm{~T}_{1}\right), 1.50$ to $2.59 \mathrm{~kg}\left(\mathrm{~T}_{2}\right)$ and 2.03 to 3.02 $\mathrm{kg}\left(\mathrm{T}_{3}\right)$ in first and last week of experiment. The highest monthly weight gain was shown by the kids in group $\mathrm{T}_{3}$ fed with higher concentrate supplement followed by $\mathrm{T}_{2}$ fed lesser concentrate and the control group $\mathrm{T}_{1}$ fed with lowest concentrate throughout the experiment. The overall effect of concentrate supplement over monthly weight gain was found significantly different as mentioned in (Table 6).

Table 6: Average monthly weight gain ( $\mathrm{kg} /$ week) of Sirohi kids in different groups

\begin{tabular}{lccc}
\hline Months & $\mathbf{T}_{\mathbf{1}}(\mathbf{M e a n} \pm \mathbf{S E})$ & $\mathbf{T}_{\mathbf{2}}(\mathbf{M e a n} \pm \mathbf{S E})$ & $\mathbf{T}_{\mathbf{3}}(\mathbf{M e a n} \pm \mathbf{S E})$ \\
\hline 1 & $1.60^{\mathrm{a}} \pm 0.03$ & $1.50^{\mathrm{a}} \pm 0.16$ & $2.03^{\mathrm{a}} \pm 0.25$ \\
2 & $1.86^{\mathrm{a}} \pm 0.07$ & $2.14^{\mathrm{b}} \pm 0.08$ & $2.67^{\mathrm{c}} \pm 0.09$ \\
3 & $2.06^{\mathrm{a}} \pm 0.10$ & $2.59^{\mathrm{b}} \pm 0.16$ & $3.02^{\mathrm{b}} \pm 0.14$ \\
Average & $1.84^{\mathrm{a}} \pm 0.66$ & $2.07^{\mathrm{a}} \pm 0.45$ & $2.57^{\mathrm{a}} \pm 0.50$ \\
\hline
\end{tabular}

The statistical analysis showed non-significant difference in weight gain at first month and a significant difference from second month onwards. The group $\mathrm{T}_{3}$ showed the highest monthly weight gain followed by $\mathrm{T}_{2}$ and $\mathrm{T}_{1}$ groups.
Table 7: Monthly weight gain in percent (\%) of Sirohi kids in different groups

\begin{tabular}{lccc}
\hline Months & $\mathbf{T}_{1}$ & $\mathbf{T}_{2}$ & $\mathbf{T}_{3}$ \\
\hline $1-2$ & 93.02 & 93.88 & 97.73 \\
$2-3$ & 55.12 & 56.94 & 59.27 \\
\hline
\end{tabular}

This is graphically depicted in (Fig. 2). With increase in quantity of concentrate supplement in the diet of kids of $\mathrm{T}_{3}$ group (from 100 to 150 gram) there was significant increase in monthly weight gain as the age advanced. The other two groups $\left(\mathrm{T}_{2} \& \mathrm{~T}_{1}\right)$ exhibited less increment in monthly weight gain as the concentrate supplement was also less in their diet. Pundlikaro (2015) and Guru et al. (2004) also reported the increase in weight gain with increased level of concentrate. Similar results were also shown by Kushwaha et al. (2016).

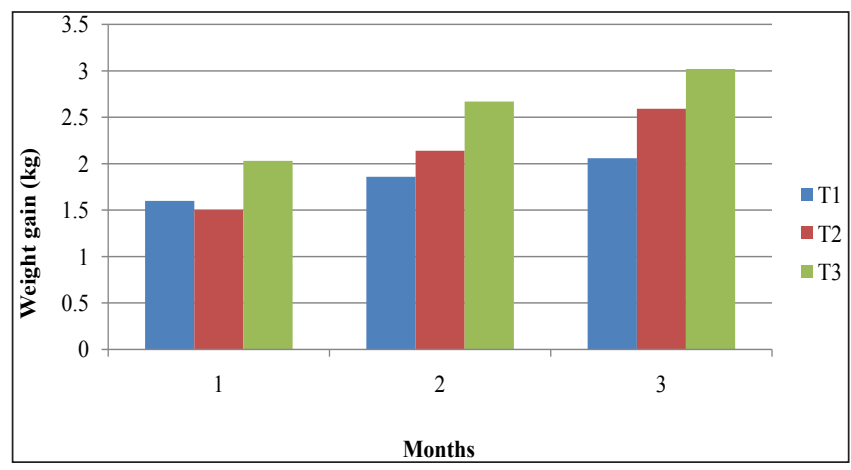

Fig. 2: Average monthly weight gain ( $\mathrm{kg} /$ week) of Sirohi kids in different groups

\section{Total gain in body weight}

The total gain in body weight 5.52, 6.23 and $7.72 \mathrm{~kg}$ for groups $T_{1}, T_{2}$ and $T_{3}$, respectively (Table 8 ). There was significant difference $(\mathrm{P} \leq 0.05)$ between three treatments. The total gain in weight of kids from group $T_{3}$ was significantly $(\mathrm{P} \leq 0.05)$ higher than kids from group $\mathrm{T}_{1}$ and $\mathrm{T}_{2}$. However, total gain in weight of kids from group $\mathrm{T}_{2}$ was significantly $(\mathrm{P} \leq 0.05)$ higher than that of $\mathrm{T}_{1}$. Guru et al. (2004) observed that at the end of the experiment kids with higher levels of concentrate supplementation tended to maintain heavier body weights. Anil Kumar et al. (2009) also recorded at the end of experiment that the body weight of the ewes which were fed higher amount of concentrates was significantly heavier than ewes receiving less amount 
of concentrates. The results obtained in present trial were in agreement with these findings.

Table 8: Average total weight gain (kg/week) of Sirohi kids in different groups

\begin{tabular}{lccc}
\hline Parameters & $\begin{array}{c}\mathbf{T}_{\mathbf{1}} \\
(\mathbf{M e a n} \pm \mathbf{S E})\end{array}$ & $\begin{array}{c}\mathbf{T}_{\mathbf{2}} \\
(\mathbf{M e a n} \pm \text { SE) }\end{array}$ & $\begin{array}{c}\mathbf{T}_{3} \\
(\mathbf{M e a n} \pm \mathbf{S E})\end{array}$ \\
\hline $\begin{array}{l}\text { Total gain in weight } \\
\text { Weight gain/day/ }\end{array}$ & $0.062^{\mathrm{a}} \pm 0.14$ & $6.23^{\mathrm{b}} \pm 0.20$ & $7.72^{\mathrm{c}} \pm 0.24$ \\
\begin{tabular}{l} 
kid \\
\hline
\end{tabular} & & $0.069^{\mathrm{b}} \pm 0.03$ & $0.085^{\mathrm{a}} \pm 0.01$ \\
\hline
\end{tabular}

\section{CONCLUSION}

On the basis of the present investigation, it may be concluded that the average initial body weight (at 4 months of age) of kids in groups $\mathrm{T}_{1}, \mathrm{~T}_{2}$ and $\mathrm{T}_{3}$ of Sirohi kids was $11.05 \pm 0.80 \mathrm{~kg}, 11.08 \pm 0.71 \mathrm{~kg}$ and $11.03 \pm 0.78$ $\mathrm{kg}$, respectively. The corresponding weight at the end of experiment in $\mathrm{T}_{1}, \mathrm{~T}_{2}$ and $\mathrm{T}_{3}$ groups were $16.57 \pm 0.80$, $17.31 \pm 0.73$ and $18.73 \pm 0.82 \mathrm{~kg}$, respectively. Thus the average total body weight gains were $5.52 \pm 0.14,6.23 \pm 0.20$ and $7.72 \pm 0.24 \mathrm{~kg}$ for $\mathrm{T}_{1}, \mathrm{~T}_{2}$ and $\mathrm{T}_{3}$ groups, respectively. Total average body weight gain of kids receiving higher level of concentrate was significantly $(\mathrm{P} \leq 0.05)$ higher than control group. It is concluded from the results that there was significant increase in weekly and monthly weight gain of kids supplemented with higher quantity of concentrate in diet. The significant increase in body weight was noticed in group $\mathrm{T}_{3}$ kids supplemented with 100,150 and $200 \mathrm{~g}$ per head per day for $1^{\text {st }}, 2^{\text {nd }}$ and $3^{\text {rd }}$ month of experiment. The kids of group $\mathrm{T}_{2}$ supplemented 50, 100 and $150 \mathrm{~g}$ concentrate feed also shown significant increase in body weight over the control group $T_{1}$. These results are only indicative and require further experimentation to arrive at some more consistent conclusion.

\section{REFERENCES}

Anil Kumar, R., Thiruvenkadan, A.K. and Iyue, M. 2009. Influence of feeding regimes from lamb hood on productive and reproductive performance of Sandyno ewes. Indian $J$. Anim. Sci., 79(5): 511-513.

Duncan, D.B. 1955. Multiple range and multiple $F$ tests. Biometrics, 11: 1-42.
Ferdous, M.R., Khan, M.J., Rashid, M.A. and Kamruzzaman, M. 2011. Effect of different levels of concentrate supplementation on the performance of Black Bengal goats. Bang. J. Anim. Sci., 40(1-2): 40-45.

Fisher, R.A. and Yates, F. 1950. Statistical tables, Oliver and Boyd, Edinburgh, London, pp. 146.

Guru, M., Tesfaye, L., Sisay, A., Dadi, H. and Assefa, E. 2004. Growth performance of arsi-bale kids supplemented with different levels of concentrate. African J. Lives. Exten., 3: 82-86.

Karim, S.A., Tripathi, M.K. and Singh, V.K. 2007. Effect of varying levels of concentrate supplementation on growth performance and carcass trait of finisher lambs. Livestock Res. Rural Develop., 19(11): 1-16.

Kharkar, K., Kuralkar, S.V. and Kuralkar, P. 2014. Growth production and reproduction performance of Berari goats in their native tract. Indian J. Small Rum., 20: 12-15.

Kushwaha, T., Tripathi, M.K., Tripathi, P., Sharma, D.K., Chaudhary, U.B. and Rajkumar, V. 2016. Effect of varying levels of concentrate feeding on growth performance, Carcass Traits, blood parameters and gastrointestinal nematodes in Goat kids. Animal Nutr. Feed Tech., 16: 25-36.

Mandakmale S., Rai B., Jagtap D.Z. and Sakhare P.S. 2012. Sangamneri a city pride of Maharashtra, MPKV/Research Publication 30/2010.

Mandebvu, P. and Galbraith, H. 1999. Effect of sodium bicarbonate supplementation and variation in the proportion of barley and sugar beet pulp on growth performance and rumen, blood and carcass characteristics in young entire lambs. Animal Feed Sci. Tech., 82: 37-49.

Mule, M.R., Barbind, R.P. and Korake, R.L. 2014. Relationship of body weight with linear body measurement in Osmanabadi goats. Indian J. Anim. Res., 48(2): 155-158.

Pundlikarao, R.S. 2015. Effect of supplementation of different level of concentrate on growth performance of sangamneri kids. Thesis, Bombay Veterinary College Parel, Mumbai Maharashtra Animal and Fishery Sciences University Nagpur.

Reed, J.D., Soller, H. and Woodward, A. 1990. Fodder tree and Stover diets for intake, growth, digestibility and effect of phenol ice on nitrogen utilization. Animal Sci. Tech., 30: 3950 .

Ryan, S.M., Unruh, J.A., Corrigan, M.E., Drouillard, M.M. and Seyfert, M. 2007. Effects of concentrate level on carcass traits of Boer crossbred goats. Small Rumi. Res., 73: 67-76. 
